\title{
Detection and molecular characterization of Clerodendron yellow mosaic virus infecting Volkameria inermis in Pakistan
}

\author{
Afzal Akram ${ }^{1,2,3} \cdot$ Aqsa Hafeez Khan $^{1,2} \cdot$ Shahid Mansoor $^{1} \cdot$ Peter Moffett $^{3} \cdot$ Rob W. Briddon $^{1} \cdot$ Muhammad Saeed $^{1}$
}

Received: 20 September 2018 / Accepted: 27 February 2020 / Published online: 1 April 2020

(C) Società Italiana di Patologia Vegetale (S.I.Pa.V.) 2020

Keywords Geminiviridae · Begomovirus · Ornamental plant · Volkameria inermis · Clerodendrum inerme

Volkameria inermis (synonym Clerodendrum inerme) is a well-known ornamental plant commonly used for hedging around lawns and gardens. In 2017 and 2019, V. inermis plants growing at two different locations in Faisalabad, Pakistan (GPS coordinates $31.39716 \mathrm{~N}, 73.02639 \mathrm{E}$ and $31.40973 \mathrm{~N}$, $73.15507 \mathrm{E}$ respectively) were found to exhibit typical begomovirus symptoms, consisting of upward leaf curling and foliar yellow mosaic. DNA was extracted from leaf samples from six individual plants and used in PCR with primers designed to amplify the DNA-A component of the bipartite begomovirus tomato leaf curl New Delhi virus (ToLCNDV-A1/ToLCNDVA2), betasatellites (beta01/beta02) or alphasatellites (DNA101/ DNA102; Zaidi et al. 2016). Amplification products were obtained with the begomovirus but not the betasatellite and alphasatellite primers. The product obtained with begomovirus primers from one sample was cloned and a single clone was sequenced. The sequence of $2760 \mathrm{nt}$ was submitted to GenBank as accession No. MH454662. The sequence showed $99 \%$ nucleotide sequence identity with isolates of the monopartite begomovirus Clerodendron yellow mosaic virus (ClYMV-[IN:Iari:06]:EF408037 and ClYMV-[PK:Sa23: Cro:12]:HE863667). Additionally virus was detected in all six samples by Southern blotting using a V2 gene probe amplified with specific primer pair CIYMV-FP(GTGTGAATATTGGT TGCATCATGTGGG)/ClYMV-RP(ACCCAGGCCTGTCT

Muhammad Saeed

saeed_hafeez@yahoo.com

1 Agricultural Biotechnology Division, National Institute for Biotechnology and Genetic Engineering, Jhang Road, Faisalabad, Pakistan

2 Pakistan Institute of Engineering and Applied Sciences (PIEAS) Islamabad, Islamabad, Pakistan

3 Département de Biologie, Université de Sherbrooke, Sherbrooke, Québec J1K 2R1, Canada
TCTTGTGACG). CIYMV has been reported to infect $V$. inermis in India (Sivalingam et al. 2011) and is an infrequently encountered begomovirus with only three other sequences available in the databases. This suggests that CIYMV has a very narrow host range. In common with earlier reports, CIYMV does not appear to associate with either betasatellites or alphasatellites (Anwar et al. 2012; Sivalingam et al. 2011). V. inermis plants are propagated vegetatively from plant shoots/cuttings which provides a likely mechanism of spread of the virus in addition to insect transmission. This is the first report of ClYMV infecting $V$. inermis in Pakistan.

\section{References}

Anwar S, Tahir M, Zaidi NSS, Briddon RW (2012) First report of Clerodendron yellow mosaic virus infecting croton. J Plant Pathol 94:S4.101

Sivalingam PN, Satheesh V, John P, Chandramohan S, Malathi VG (2011) Complete genome sequence of an isolate of Clerodendron yellow mosaic virus - a new begomovirus from India. Acta Virol 55:357-360

Zaidi SSA, Shafiq M, Amin I, Scheffler BE, Scheffler JA, Briddon RW, Mansoor S (2016) Frequent occurrence of Tomato leaf curl New Delhi virus in cotton leaf curl disease affected cotton in Pakistan. PLoS One 11:e0155520

Publisher's note Springer Nature remains neutral with regard to jurisdictional claims in published maps and institutional affiliations. 